\title{
Re-imagining Global Union Representation Under Globalisation: A Case of Seafaring Labour and the Nautilus International Cross-border Merger
}

\author{
Victor Oyaro Gekara, School of Business IT and Logistics, RMIT University, Australia \\ Iris L Acejo, Seafarers International Research Centre, Cardiff University, UK \\ Helen Sampson, Seafarers International Research Centre, Cardiff University, UK
}

\begin{abstract}
This paper reflects on the opportunities and challenges for labour movement revitalisation through cross-border organising. It considers whether, and how, unions may innovate and present a united front, where transnational employers actively seek to divide and fragment labour for cost advantage. The analysis examines the relevance of path-dependency theory to an explanation of some of the observed limitations to innovation and adaptability among unions. In the light of growing debates about union renewal in the context of globalisation, we examine the obstacles to an effective response to global capital by national unions using the illustrative example of Nautilus International (NI). We conclude that cross-border union organising strategies, such as adopted by NI, are essential to sustain effective representation but great challenges, related to path-dependency exist.
\end{abstract}

\section{KEYWORDS}

cross-border unions, innovative unions, Nautilus International, path-dependency, union capacity

\section{Introduction}

That the power and influence of the global labour movement has drastically waned over the past thirty to forty years is well established in the literature (e.g. Hyman and Gumbrell-McCormick 2010). The combined effect of neoliberal state policies and targeted multinational corporate (MNC) strategies in the development and supply of labour mean that the capacity of unions, in terms of membership, financial and bargaining power, has declined. Concurrently the ability of multinational business to segment and exploit labour internationally has increased during this period, resulting in an overall deterioration in the situation of workers, characterised by work intensification, decreasing net pay and casualisation. In this context the shipping industry, presents us with an ideal opportunity to study some of the results of such trends not least because the industry is extensively globalised, and in many respects, exemplifies the growth of multinational corporate power, the withdrawal of the state and the decline of union capacity.

The labour situation in the international shipping industry is not one of a simple reversal of labour supply dominance, from high-wage North to low-wage South. As such it is not possible to conclude that what has been lost by unions, in terms of members and financial resources, in the North, 
has been gained by unions in the South. Such a view would imply that the influence of the labour movement in the industry remains generally undiminished. A close look reveals that the developments in the political economy of international shipping in the past three decades are anything but simple, and that the implications for labour are extensive. The advent of massive 'flagging out' ${ }^{1}$ in the $1970 \mathrm{~s}$ and 80s not only allowed ship owners to circumvent stringent regulation by national flags (particularly regarding seafarer employment), and access cheaper crews overseas but also enabled them to effectively challenge the organising influence of unions.

Firstly, a lot of open registry flag-States (commonly referred to as flags of convenience [FoC]) lacked both the will and the ability to effectively regulate the labour practices of the shipping multinationals that owned and operated vessels in their registry, thus ship owners were free to recruit seafarers from anywhere with minimal compliance with requirements relating to nationality, minimum crew, and work and employment conditions (Cooper et al. 1999, Alderton et al. 2004). This had huge implications for the development of supply of labour in the sector. From a situation where the majority of seafarers were supplied by a handful of established (mainly European) maritime nations, new (cheaper) suppliers such as the Philippines, Indonesia and India rapidly grew to a dominant position as sources of seafarers. As a result, within two decades (1980s and 1990s) the numbers of seafarers in developed maritime countries had dwindled considerably in global market terms. Thus, by the mid2000s the OECD group of countries in total supplied only 25 percent of the total number of seafarers while Asia, including the Indian Sub-continent, supplied 44 percent. The remaining seafarers came from Eastern Europe (18 percent) and Africa and Latin America (BIMCO/ISF 2005). In this regard, Priers and Seeliger (2013: 26) argue that the increasingly compromised state of global labour is largely due to 'an erosion of national labour regulation regimes' leading to 'almost unregulated international competition'.

Secondly, since collective bargaining agreements are normally negotiated with trade unions of the flag-State, the shipowners were able to escape pressure from the much stronger unions in established maritime countries in the North by recruiting more seafarers from the new labour supply countries of the South. The implications of these developments for union capacity were far reaching. The decline in job opportunities for seafarers, and consequently the numbers of seafarers in developed countries, meant that by mid-1990s, the majority of seafarers came from developing countries (Glen 2008) where unions lacked the capacity to effectively engage with multinational shipping companies, and where the tradition of unionisation was relatively weak (Lillie 2004). The overall effect was therefore a general decline in union capacity in the sector internationally. It has thus been observed that the overall effect of flagging out, which epitomises the impact of globalisation in the industry, is exposure of seafarers internationally to the largely unchecked, minimum-cost, maximum-profit employer strategies (Bergantino and Marlow 1997). Furthermore, taking advantage of the varying economic contexts in different labour supply regions, employers have managed to extensively segment global shipping labour, producing divisive competition between North and South, and to some extent, East and West segments, characterised by deep tensions over 'stolen' jobs. Under these conditions and as national unions focus on protecting their members' jobs at home, possibilities for a concerted and effective international response to global capitalism within the industry may seem thin.

In developing our analysis of the possibilities of, and obstacles to, effective union response to labour's declining fortunes we draw on the NI merger and present it as a unique and bold step in the renewal of trade union organisation. However, we critically interrogate the potential to apply the model more broadly given the context of competition, mistrust and tension, which characterises the seafarers' global labour market. 


\section{The Debates}

The analysis draws together three important and closely related debates. Recent developments, associated with economic globalisation, have transformed the processes by which labour is sourced (Sander 1996, Munck 2002, Foreman-Peck 2007, Peck et al. 2005), with the consequence that workers in certain sectors have become increasingly mobile globally and often lead a trans-national existence (Hannerz 1996, Kennedy and Roundometof 2007). These developments have also resulted in growing employment vulnerability and deteriorating work experiences for many workers around the world. Similarly, the incremental expansion of the power and influence of multinational capital under neoliberal globalisation has significantly undermined the influence of the labour movement, which currently struggles to maintain relevance and effectiveness in its core purpose of organising and defending the rights and interests of all workers (Baccaro et al. 2003, Priers and Seeliger 2013). An important related debate, therefore, regards labour's renewal and the capacity to rejuvenate organisation and representation locally and internationally (Cumbers 2004, Borgers 1999, Gallin 2002). Contextually it is important to consider the debates in light of the decline in trade union membership in some OECD countries (such as the UK) in recent decades (Gennard and Judge 2005, Boeri et al. 2001, Dawson 2003). In response to the decline in union influence and the related expansion of the influence of multinational employers, a pertinent question for academics and unionists alike has been to consider how trade unions can best respond to such rapidly changing circumstances. Addressing this question has led some authors to consider the relevance of path dependency theory to trade unions (Holtgrewe and Doellgast 2012, Morrison et al. 2012). Additionally the spatial and institutional embeddedness of trade unions has been examined in recent literature (e.g. Cumbers 2004) with the conclusion that it presents a major obstacle to an effective response (and adaption) to influential changes in the global political economy.

\section{Methods}

The material informing the discussion is drawn mainly from a study of the recently established cross-border union - Nautilus International - and augmented with data collected as part of a separate study on transnationalism in the seafaring sector. The main study involved qualitative research conducted between 2005 and 2011. The study utilised formal in-depth interviews and informal discussions with senior officials and executive members of the union, a continuous review and analysis of relevant content published in the Nautilus Telegraph (the NI official journal and in-house monthly newspaper), an analysis of the union's annual returns to the UK Certification Office, and some limited participant observation at the union's various meetings.

In total, 20 formal interviews were conducted with several threads of follow-up correspondence. Many informal but relevant discussions also took place during visits and attendance at union meetings. Thus, the researchers monitored the evolution of the merger until and after its launch in May 2009.

The second study focused on labour transnationalism and its implications for the wellbeing of seafarers. It involved semi-structured interviews complemented by non-participant observation aboard a container ship by one of the researchers. The researcher in this study spent 41 consecutive days observing and speaking to seafarers about their work, employment and life experiences. The data from the two separate studies have been revisited and analysed with a view to shedding light on the challenges posed by globalisation, for seafarers and their unions. The main focus of the analysis was two-fold. Firstly our intention was to examine the ways in which the ship as a microcosm of the global shipping industry illustrated the complexities of organising international labour in multinational workplaces, where seafarers work on different terms and conditions according to nationality. Secondly 
we wished to highlight the challenges facing unions with regard to creating representation structures for workers across different nationality divides in a multinational and highly competitive workplace.

\section{The Globalisation Challenge for Seafarers' Unions}

Lane (1999) has characterised the shipping industry as the 'ultimate embodiment of deregulatory principles'. Prior to the mid-1970s the international shipping industry was organised, and operated, from within an embedded shipping tradition, mostly in Europe. Moreover Europe was the focal point of the industry, where the majority of ships were built, registered, crewed, managed and operated. The dominant proportion of the world's fleet was registered to national 'flags' and thus abided by a 'code of operations' established via the joint effort of employers, unions, government agents and voluntary organisations (see Lane 2000). With regards to work and employment in the industry, Lane (2000: 4) observes that 'at the very least, employment conditions and the engagement and discharge of crews were supervised by agencies guided by laws, rules and procedures agreed by joint bodies of shipowners and seafarers'. However, following a series of crises in the 1970s, including the oil crises, a slump in world shipping markets and a huge tonnage surplus following the reopening of the Suez Canal in 1975, shipowners came under increased pressure to reduce operating costs (Marlow and Bergantino 1997). This led them to shift the registration of their vessels to offshore ship registries (which came to be known as Flags of Convenience or FoCs) providing a tax and regulatory haven for shipowners (Rodney 1981, Sletmo and Holste 1993, Yannopoulos 1988). These registers rapidly became dominant; from 6 percent in 1950 the percentage of the world fleet under the 10 top open registers sprang to 27 percent in 1975 and 54 percent in 2002, according to UNCTAD statistics. States no longer held much influence over shipowners regarding the recruitment, training and employment of seafarers and, faced with the potential decimation of national fleets, many embedded western maritime states responded with the establishment of second and international registers, which were essentially diluted regulatory regimes as compared to national flag establishments. These allowed shipowners to employ crews of any nationality in addition to paying reduced taxes (Sletmo and Holste 1993). Consequently, reduced seafarer training and shrinking employment opportunities led to a drastic decline in the number of seafarers in industrialised (OECD) maritime nations. As Sletmo and Holste (1993) observe, flagging out thus marked a significant departure in the globalising trajectory of the shipping industry.

In this paper we argue that these developments not only affected the organisation and regulation of the industry but also the capacity of trade unions to effectively organise and represent seafarers working worldwide. We suggest that globalisation and flagging out undermined trade unions in the sector. Labour laws and union structures in new labour supply countries were not strong enough to challenge powerful multinational employers, often operating with the blessing of neoliberal governments. Equally the formerly stronger unions in established seafaring labour supply countries were increasingly rendered ineffective because of declining capacity. Thus, as Harvey (2006) also observes, globalisation (in this case epitomised by the flagging-out process), has had the impact of undermining global solidarity and, has indeed, created national and regional antagonisms, thus creating an increasingly challenging environment for union internationalism.

The globalised nature of the shipping industry has been extensively analysed (e.g. Lillie 2004, 2006; Bloor and Sampson 2009) with the consistent conclusion that it represents an important example of capital's 'footloose' character (also Crouch and Streeck 1997). The international ownership and operation of tonnage, the global nature of crew sourcing and employment, and the ease with which a ship's nationality can be shifted from state to state (Alderton et al. 2004, Wu 2004) have all been cited as features of the industry which are consistent with this conceptualisation. As Kahveci and Nichols 
(2006) observe, apparent ownership and nationality of assets in the shipping industry are both vague and 'fictitious' because they are increasingly difficult to ascertain because they can be switched and shifted with extreme ease, thus allowing extensive flag-surfing and labour-hopping. Whereas this arrangement presents obvious benefits for shipowners, in terms of operating costs, it offers many challenges for labour, relating to the deteriorating nature of employment terms and conditions and the organisation and representation of the workforce (DeSombre 2006, Gekara 2010, Sampson 2012). Equally, it presents significant challenges for national States regarding effective control and regulation in the industry (Bloor and Sampson 2009).

This situation is, however, not unique to shipping. In general terms, the challenges facing labour have been occasioned by a number of factors, among them: the systematic decline and/or withdrawal of State support under neoliberal capitalism; geo-political obstacles to international organising; and a general decline in the effectiveness of organised labour (e.g. Munck 2004, Fiorito and Gallager 2006, Lévesque and Murray 2010). All these have converged to enhance employment vulnerability for workers at different points along the global commodity supply chain, while at the same time diminishing union capacity.

Owing to the mobility of both shipping corporations and their primary assets - ships - the industry presents an excellent opportunity to consider union response to the rise of global footloose capital. Significantly, cross-border union collaboration is evident at various levels of the industry. The best example is the work of the Global Union Federation - the International Transport Workers Federation (ITF). With the breakdown of the central regulatory framework, following the advent of flagging out, the large majority of seafarers (employed on board open-registry vessels) found themselves without effective union representation, without State legislative protection, and facing bottom-line focused employers (Cooper et al. 1999). The ITF therefore became the voice of seafarers globally and drove the fight for equitable pay and fair, uniform-working conditions. The ITF website shows that as of 9 December 2012, the GUF brings together 690 affiliate organisations across 153 countries and represents 4.5 million workers worldwide. Its affiliates include national seafarers unions, dockworkers' unions and other unions in the wider transport sector.

At a more regional level there have been examples of cross-border working in America and Canada, including the International Organisation of Masters, Mates and Pilots (MM\&P), which is the marine section of a bigger US-based international union organisation - the International Longshoremen's Association (ILA) ${ }^{2}$ and the Seafarers International Union of North America (SIU) ${ }^{3}$ (see Janus 1978, Herod 1997, Chaison 1980). Collaboration among national unions is also apparent, albeit on an informal and ad hoc basis. This is largely as a consequence of the multinational nature of modern crews, which means that host-country unions are routinely called upon, and expected, to offer all necessary assistance to foreign crews on board vessels within their waters. Though informal, such collaborations represent an important characteristic of organising in the sector.

We argue that in recent years growing divisive international competition in the sector has greatly undermined the traditional spirit of cross-border solidarity in the sector. With the bottom-line driven segmentation of the seafarers' labour market, competition between regional (even national) labour segments has intensified creating strong undercurrents of tension and suspicion (see Priers and Seeliger 2013). Indeed, some of the challenges that have punctuated the ITF's global organising success story illustrate the fragility of the international seafarer labour solidarity. In the early 1970s, for example, its core and most important campaign, the FoC campaign, came under threat when the Indian and Chinese national seafarers unions sought to break away over the perception that its work was singularly focused on promoting the interests of seafarers from developed countries at the expense of job opportunities for those from the new and competing labour supply countries (Lillie 2004). Such 
withdrawal would have seen an exodus of affiliates from developing labour supply countries and collapse of the Federation.

\section{It Is Them Against Us: Workplace Competition, Tensions and Suspicion}

In shipping, the ship is the most important unit of production. It is the equivalent of a factory in the manufacturing sector. Allowing for differences in specific trades, ships generally present similar workplace features. The most significant difference when compared to land-based workplaces is that, for seafarers, the ship-board workplace is also their living space for a significant portion of the year. Allowing for differences in specific trades, ships generally present similar workplace features. With the increasing globalisation of the seafaring sector over the past four decades, the ship has become a highly multinational workplace, with workers often drawn from different regions and nationalities. Whereas this is not an unusual setting in the emerging global economic order, it has significant implications, considering the working and living arrangements highlighted above.

Perhaps more importantly, and in relation to union organising, the shipboard workplace is an isolated, mobile unit, mostly distant from shore-based union structures. That is, unlike in a factory where resident union representatives organise workers, there are generally no such on-site union structures at sea. Furthermore, the combination of increasingly voyage-based, temporary employment contracts and the multinational composition of the crew mean that no single union has any direct influence at the workplace. Union representation is therefore rather remote.

For these reasons we interrogated our data for indications of the extent to which seafarer solidarity at the workplace, among members of different nationalities, is undermined by the broader politics of a globalised labour market and notions of competition within it. The shipboard workplace provided a microcosm of the sector, and offered an appropriate setting for this kind of (individual-level) analysis. We also sought similar evidence, but at the union level, focusing on views of union officials. For this (institutional-level) analysis we have drawn on the accounts of NI officials and executive members, regarding the challenges of negotiating and establishing a single cross-border union.

The individual-level interview and observational data collected on board ship reveal strong tensions and deep-seated suspicion between the different seafarer nationalities. The ship carried a total of 25 seafarers -12 officers and 13 ratings. The crew comprised three different nationalities, Filipinos (14), Indians (10) and Sri Lankans (1). Two out of the 14 Filipinos were officers (second mate and electro cadet) except for one rating, and majority of the Indians were officers.

The data indicated that suspicion and tensions between the different nationality groups on board were representative of the global labour market situation, characterised by cutthroat international competition for jobs. For example, one interviewee felt that 'his people' were discriminated against in terms of workplace rank in favour of 'others' who apparently got good positions when they were not necessarily better qualified:

...we have here 4th engineer [nationality $\mathrm{X}$ ], he is not that good but there is another 4th engineer [Filipino] but was backstabbed. He was much better but he was sent home because of that. If they made a mistake, then that is just fine with them but if it is Filipino then you are dead. So you have to be careful. You really have to be careful if you are a Filipino because they have a different treatment. (Second engineer, April 2009)

The issue, seemingly, is not simply that the 'other' holds an undeserved position but, more importantly that it is because of backstabbing by the 'other' on nationality grounds that 'we' are denied the positions. There is therefore, seemingly, 'bad blood' between the two nationality groups largely caused 
by competition and suspicion. The quote further suggests that ship managers and owners are also partisan in their allocation of positions because they seem to be influenced by the 'backstabbing' of one group against the other. The interviewee went on to emphasise the disadvantaged position of the Filipino crew in the following terms:

Like for example, they will say in a Filipino crew, 4th engineer, 'you are not fit for a big ship.' But then, that other one they hired is worse but they don't admonish that way. (Second engineer, April 2009).

Whether this portrayal of the employers' view is accurate cannot be confirmed but it reveals the extent of inter-nationality group competition and suspicion. Another interviewee further illustrated such tensions as follows:

...you know what, [nationality $\mathrm{X}$ ] and [nationality $\mathrm{Y}$ ], they see Filipinos as competitors on the job. They can use those things against you. The [nationality $\mathrm{C}$ ] whites have no problem. It is an established fact that we will always be inferior against them because they have shipowners. We Filipinos will admit that we think this way: 'who are you to treat us as inferiors'. They [nationality $\mathrm{X}$ and $\mathrm{Y}$ ], are like that to us too. The competition is still there. The [nationality $\mathrm{D}$ ] may be somewhat behind but not X, Y and Z]. (Second officer, March 2009)

This quote sums up the type of crew relations to be found aboard many ships operating with two or three nationalities aboard. ${ }^{4}$ It portrays a highly racialised workplace where rank and nationality are often related (see Sampson 2013) and where competition in the labour market is racially constructed, so that it is 'them' against 'us'.

Put together, the interviews confirm that the problem facing workplace solidarity and crossnational organising is highly complex. In the emerging global economy where employers segment the global workforce and pit each against the other in a race to the lowest wage bill, the breakdown of labour's international solidarity cannot be reduced to a simple Northern vs. Southern divide. The prevailing situation seems to be one where nationals of individual countries are highly aware of the competition which exists between them, militating against the formation of cross national alliances. Because of the effective manner in which employers have exploited fears about job losses and have sustained financial advantage by building on the extent to which groups are willing to undermine each other, different crew nationality groups are unable to combine effectively to present a single voice at the workplace. The extent to which employers have been successful in this is illustrated by the way in which even amongst such small crews, which may be thought of literally and metaphorically as 'all in the same boat', crew relations are undermined. One interviewee explained that:

I can't really say that we are close. But sometimes it can't be helped that there's a bit of discrimination, belittling. You cannot avoid it. This doesn't mean though that everything that they can do, you cannot do. We have many foreign officers in our ship who don't really know what they are doing. (Able-bodied seaman, March 2009)

Workplace solidarity is also undermined by the nature of the employment contracts that are increasingly used by shipowners. Whereas previously seafarers were mostly employed on a permanent or long-term contract basis these have been gradually replaced by short-term contracts, often voyage-based. 
Therefore, as another interviewee explained, seafarers lack 'the motivation to reach out because they 'don't know when you will work again'. So, you 'just do your job'.

Unsurprisingly, the tensions highlighted in the foregoing discussion are also highlighted in NI's recent research which confirms that 'multinationalisation has led to on-board isolation and cultural segregation' (Umney 2012: 76). Significantly, these tensions also presented a key challenge in the initial stages of establishing NI as a joint, seamless cross-border union bringing together hitherto separate and independent unions in different countries. As explained in Author (2010) this visionary idea proved difficult to sell to ordinary members whose opposition to such merger was informed by national level experiences of lost job opportunities, and thus a heightened individual and collective awareness of the intense nature of international competition on the labour market. The key concern therefore was to preserve and improve their chances against other nationalities because, according to many, the British and the Dutch were, at the end of the day, competitors for employment opportunities (for European seafarers) in a shrinking job market. As explained by a senior NI official, a common view among ordinary members tended to be that the best way to fight for British seafaring jobs was, 'to fight for [our] jobs locally and not for the [others'] jobs as well' (NI Official April 2006). Some, apparently, argued that the new union would not be able to fight for [local] jobs because it will have to look after them ... as well' (NI Council Member, December 2010). At a more institutional level, tensions existed and still do exist, regarding loss of national union identities (for more details on the challenges for the merger at the initial stages see Author, 2010).

\section{Seafarers' International Solidarity: The Merger Behind the NI}

Nautilus International is a specialist union of maritime professionals which organises internationally, principally across European borders and within the British, Dutch and Swiss maritime and inland water transport sectors. It is a product of a unique cross-border union merger, initially between the Federatie van Werknemers in de Zeevaart (FWZ) of Netherlands and the UK's National Union of Marine, Aviation and Shipping Transport Officers (NUMAST). It came into existence in May 2009 after nearly a decade of negotiations and preparation. The original two branches, Nautilus NL and Nautilus UK have been recently joined by the maritime workers of Unia of Switzerland.

The vision behind the merger leading to NI may be understood at two different but related levels. First, as a localised and functional response to the decline experienced by the two unions in terms of membership and associated financial and political influence (Gekara 2010). The data show that the primary and immediate purpose of the merger project was to create an instrument through which the two unions, and any others which would be interested in subsequently joining, would pool resources to create a larger, stronger and more influential entity with capacity 'to provide a voice for maritime professionals nationally and internationally' (NI Official, April 2006). Mark Dickinson, then NI designate General Secretary, in an interview, summed up this mission thus:

We needed to build our strength... we're going to make sure that we are bigger, stronger and have more resources, to maintain our relevance, maintain our strong member base in the maritime industry and we will be then better able to more effectively engage and campaign at the global level. (NI GS, January 2009)

Its conception arose against a background of decline in union capacity more generally, particularly amongst unions in industrialised high-wage developed countries (see Ebbinghaus and Visser 1999, Tope 2009), where many job opportunities were exported to the low-wage South in a wave of manufacturing outsourcing. Following massive fleet flagging out and increasing employer appetite for 
low-wage seafarers from the new seafarer supply countries, mostly in Asia, maritime unions in the OECD countries experienced a drop in their membership. Data obtained from the two Nautilus Union partners indicate a steady reduction in membership between 1975 and 2009 (see figure 1).

Figure 1: NI membership trends 1975-2009

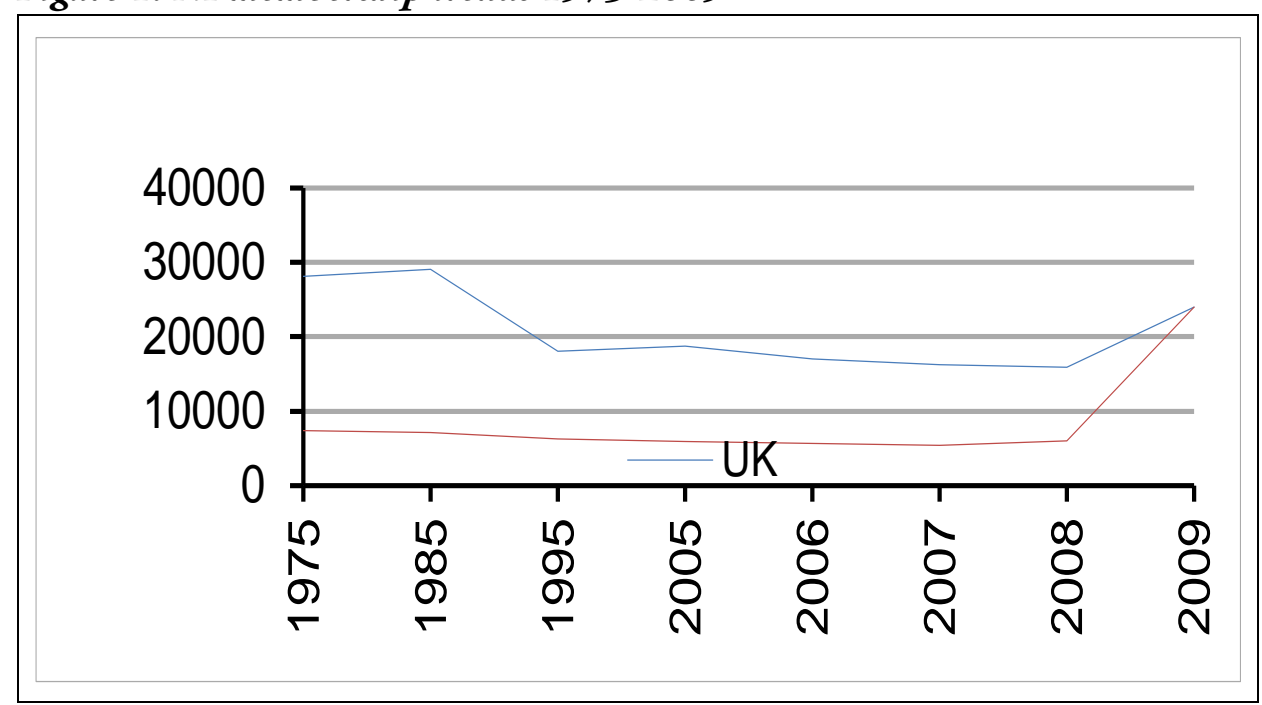

Source: Certification Office (UK)

To this end the merger succeeded in that the pooled membership amounted to 25,000 in 2009 and almost 26,000 in 2011 when UNIA, the Swiss union, joined Nautilus. Accordingly the General Secretary observed in an interview in 2010:

Clearly there's more resources in the kitty than there was before. There's more members in the union which gives us renewed hope... We're a bigger, stronger organisation now because we're together. (NIU GS December 2010)

The second level at which the union merger can be understood is in relation to the extent to which the NI vision went beyond the immediate and functional purpose of the union to a 'higher level' of international unionism in line with Cumber's (2004) idea of unions organising across borders and presenting an alternative to neoliberal capitalism. The data show that the merger's conception did indeed contain a vision for a more unified international seafarer workforce, which could, according to Marcel Van Den Broek, then FWZ Chairman (Voorsitter) (currently one of the NI Assistant General Secretaries), more effectively respond to the growing power of employers in the sector and improve overall seafarer conditions:

Look, they can go anywhere and they can recruit from anywhere...If we are united across the same borders that they recruit then we can say, hang on, you cannot treat them differently...offer different terms here and different there, we are united, we speak the same voice. (April 2008)

However, this enhanced ability to respond to multinational employers was mainly pegged to an immediate concern for the increased momentum that would flow from increased membership and 
resources. The primary focus appeared to be Europe and the target organisations were a diminishing sample of like-minded unions. In response to a question about whether NI envisaged expansion to include unions in regions in direct competition over maritime jobs, the General Secretary provided the following explanation:

...in the short term no, but I think in the long term definitely. I mean that was part of the rationale for Nautilus International for the Dutch and the Brits to come together. We felt that our growth area would be primarily Europe. That would be our first objective, to grow in Europe. Okay, so we're talking to the Swiss ... We know that there is a lot of interest from other seafarers unions. Any number of those smaller Unions that are feeling their way within the EU in particular ...

He went on:

In an ideal world...one day when I am long gone, we might achieve true international trade unionism or at the very least a European Union for Seafarers. (December 2010)

The problem with focusing on Europe, however, is that even with recent efforts to revive the seafarer labour market, the region's seafaring force is in gradual decline since shipowners no longer recruit and support training for significant numbers of cadets in Europe (Gekara 2009), and continue to search for even cheaper sources overseas (Sampson 2012). The result is a diminishing pool of seafarers in European countries. This situation is also acknowledged by union officials:

It's likely, given the crewing and training policies of British shipowners that it's going to decline... Even just to stand still at the levels we are today is going to be a challenge, never mind making it grow. (NIU Official December 2010)

In this respect, Umney (2012: 76) observes that although Nautilus International is in a 'relatively strong market position compared to other seafaring unions' based on the prevailing global shortage of officers and prestige with which British officers are regarded internationally, it faces a great threat in terms of membership decline because of continuing 'demographic attrition'. It might seem therefore that, in order to achieve the objective of greater strength and 'speak[ing] in the same voice against employers' exploitative strategies 'across the same borders that they recruit' (see p. 9 quote), a more effective strategy would be to seek links with unions in the populous seafarer labour supply countries, especially in Asia. Yet, as explained by the General Secretary, although the future vision is to have a strong foot in Asia, the furthest they were able to consider at the moment was New Zealand and possibly Singapore:

We're quite keen to get a foothold in Asia. We have always been close to the New Zealand officers union and of course they are geographically located in Asia but it's not really Asia in the sort of - in the normal sense of that word. So we are in discussions about to launch a partnership initiative with the two Singaporean maritime Unions to build on the existing presence we have there. (NI GS, December 2010).

The initial focus on Singapore and New Zealand as the initial potential partners (in Asia) is highly problematic in as far as it perpetuates the restrictive path-dependence. Not only are these two 
destinations highly developed, high-wage economies (meaning that they exhibit similar downward trends in terms of seafarer numbers and, by extension, union membership), an amalgamation with them does not greatly enhance the Union's influence against the global body of employers. Establishing an effective 'foothold in Asia', that is, developing, low-wage Asia (including Philippines, Indonesia, India and China), which is now the dominant source of seafaring labour, would not only renew the strength and effectiveness of organising in the sector but would also gradually redefine and change the embedded attitudes of competition and suspicion exhibited at the workplace. For unions aspiring to effective international organisation and representation it would represent a break away from constraining traditions to embrace a new and changed employment context. It is worth noting, in this regard, that the marketplace competition-driven animosities exhibited at the workplace not only weaken the workers' power position but, more importantly, create stressful work experiences with health implications and implications for staff turnover and the overall quality of crew output.

Why then is this approach, which from the outside seems most obvious, not at the top of the NI agenda? The next section examines this question in more detail, with regard to the key obstacles in the way of NI's innovative organising approach.

\section{Path-dependency as an Impediment to Cross-border Solidarity}

As highlighted earlier (sec. 2) a major impediment to effective cross-border solidarity among unions relates to their institutional and spatial embeddedness (Cumbers 2004). A recently growing theory within renewal debates is path-dependency, which posits that change within organisations could be enhanced or hindered by adherence, and lock-in to established organisational structures and practices (Peters et al. 2005, Pierson 2000, Steinmo et al. 1992). In a related analysis Johns (1998) examines two models of organising. He designates 'accommodationist solidarity' as the form of organising whereby focus is on securing and maintaining local interests, while in 'transformatory solidarity' unions seek cooperation across geo-political borders in order to more effectively respond to the segmentational and divisive strategies of global capital. In relation to unions, path-dependency has mostly been examined from the perspective of spatial embeddedness - embeddedness to the national space - being an obstacle to organisational change, particularly with regard to uniting unions across national and geographical borders (Cumbers 2004). In few studies has such path-dependency been analysed with positive outcomes. In Morrison et al. (2012: 329), for example, it is found that drawing on established Soviet legacies resulted in 'a well-organized representative union capable of challenging management at the negotiating table, as well as on the shop floor'. The authors however acknowledge that such positive outcomes from path-dependency are rare, thus suggesting that the more likely effect is a hindrance to effective and positive organizational change. Investigating the challenges facing Ver.di (the conglomerate service sector union in Germany), Holtgrewe and Doellgast (2012:327) conclude that the union 'faced large challenges in moving beyond established strategies due to the growing incompatibility between established industrial relations, its own organizational structure and the changing structure of firms and industries'. Thus, commentators of path-dependency and embeddedness in relation to union organising suggest that the majority of union strategies lie within the accommodationist' sphere as opposed to 'transformatory, particularly with regard to internationalisation.

We locate the analysis of NI 's internationalisation agenda within this discussion and argue that, to a great extent, the leadership has attempted to break with this tradition but been constrained by, among other things, overwhelming pressure to adhere to their members' localised expectations, which are informed by a traditional construction of the place, role and purpose of unions. It must be noted that the merger idea and the vision it contained was a conception of the NUMAST and FWZ 
leadership. To operationalize and realise it, however, a mandate was sought through democratic processes, which involved extensive consultations and a final members' ballot (Gekara 2010). An analysis of data relating to the process reveals significant resistance amongst the membership across the divide, mostly based on fear of losing national identity and a focus on immediate issues facing the members at the national level. Such fears were apparently so great that even the use of the word 'merger' to describe what was taking place 'was always a sensitive concept anyway' (NI Official July 2011). Significantly, discussions on the internationalisation vision show that these fears seemed to magnify when considering mergers with unions from the developing South. In one such interview a member of the Council explained that he could 'not see it working' because 'we are in competition with each other, how can we merge?' (NI Council member, Dec 2010).

The first major impediment to union internationalisation in this case, therefore directly relates to John's dilemma of 'accommodating' vs 'transforming'. This situation is best captured in the Union's General Secretary's attempt to describe the Union's position on global/local issues in the following interview extract:

I am elected by my members, we are democratic. We are all autonomous; we are masters of our own destiny. That's how we want it to be. We want to continue to have control over what we do as a union, what my members want me to do for them in order to protect their jobs. We protect our members, that's what we do and we look after their interests. We're not concerned with anybody else's interests. Of course the reality is that you do have to become concerned with the bigger picture because you're an actor in that big picture. (NI GS December 2010)

The conclusion of this extract is indicative of the dilemma but the overall emphasis is very much on servicing the local needs and aspirations of members. It might therefore appear that in its attempt to transform the organisation's organising focus from local to international, the NI leadership is faced with pressure from a core membership which leans more towards accommodationism. Umney (2012: 73) reaches a similar conclusion when he observes that the material conditions which enable internationalist frames to gain traction simultaneously limit their progression into a "transformatory solidarity"'.

The second impediment to international mergers between unions in competing labour markets relates to a notion of 'like-mindedness' referred to extensively in the interviews: a construction of a Union-type which then defines who can and cannot be admitted into NI:

We've always said that our expansion would be on the basis of like-minded Unions. Unions that subscribe to Nautilus's vision. (NI Official December 2010).

Seemingly, this defining notion of 'like-mindedness' is articulated in three ways: firstly the term seems to refer to the 'purity' of the homogeneity of memberships - maritime professionals. Thus, maritime unions which represent workers in other related sectors, in addition to seafarers, would be automatically excluded. The complexity of organising in the seafaring sector, with regard to the question of membership homogeneity, is great and merits separate and deeper analysis. Suffice it to say here that a further problematic stratification of union-groups along the lines of rank and section exists and relates to the evolution of unions. Thus, in many countries there are separate unions for officers and for ratings. Further divisions exist between unions for engineers and for pilots. ${ }^{5}$ This level of stratification further problematizes the notion of 'like-mindedness' and complicates chances for an allinclusive representation even at the nation-State level. Thus, NI is more of an officers' union than a 
ratings one. In the UK case for example, although NUMAST never had a specific policy excluding ratings, the existence of a parallel and strong union representing ratings (the $\mathrm{RMT}^{6}$ ) meant that officers gravitated one way (to the RMT) as did ratings the other (to NUMAST). This division is further diluted in NI because of the largely inclusive nature of the Dutch and Swiss branches. To complicate the setting further, NI is not an exclusive seafarers' union as it also represents shore-based maritime professionals. Nevertheless, the question of member homogeneity is presented as an important selection, or rather exclusion, criterion for NI.

Secondly, the 'like-mindedness' notion refers to a harmony of organising ideology, whereby potential merger candidates must have similar approaches towards organising and representation. At the initial stages one rather obvious candidate was, for example, ruled out for being too militant in its approach to industrial relations.

Thirdly, it apparently refers to, and excludes, unions whose members are undercutting terms and conditions in competition for jobs, as explained by a Council member:

I think we've got a long way to go before we reach that situation because our members, primarily the British and Dutch members might say no, 'but they're not like minded Unions because they're taking our jobs'. (Union Council Member, December 2010)

Similarly an official added:

...if you asked someone in terms of what like-minded Unions means, essentially, the argument would come down to whether they were cheaper than us. Because the ship owners would say hang on a minute, I'm replacing you with these guys but these guys are also your members... When you get redundant in six months time I'll defend you but right now, hang on a second. (NI Official July 2011).

Just like the global-local dilemma, this 'like-minded' notion designates a path to which the union is forced to adhere even as it tries to innovate and adapt to changing circumstances; a script which says, 'we have always organised and represented maritime professionals in Europe based on a specific ideology. Any innovation must be in adherence to this script'. The problem, however, is that this script constrains innovation options greatly. It is worth pointing out that, as a result of both sides insisting on safeguarding established national spaces, the aforementioned negotiations with the New Zealand Merchant Service Guild (NZMSG) broke down and were abandoned in 2011. Apparently it was the Guild's reluctance to accept reassurances regarding domestic autonomy that broke negotiations. Officials explained that NUMAST and the Guild had decades before failed to agree on cross-border merger negotiations due to similar issues of autonomy.

Another constraint seems to be the need not to be 'seen to be creating a competing organisation to the ITF' (NI Official, April 2006) while at the same time forging a distinct path alongside it. The dilemma is articulated by an official as thus:

Well as I say, you either hand over responsibility to the ITF and say 'you look after my members, we'll just become a branch of you - an agent of you'. Or, well, like-minded affiliates will do it, get together and organise within a sector like we're trying to do. We can still be - I believe passionately - we can still be positive and strong supporters of the ITF within that structure. (NI Official December 2010) 
In developing a large scale NI, consideration would indeed need to be given to the relative roles of the new NI and the existing ITF given that its expansion would amount to organising national unions across borders to recapture the space, which, as national flagged ship crews have declined over the years relative to open registry crews, has increasingly come under the organising domain of the ITF (Lillie 2004).

\section{Conclusions}

In examining union renewal, Gallin (2002: 247) wonders why a simple idea such as merging unions of different countries is regarded as utopian and suggests that cross-border union mergers should by now be widely practised considering the environment in which labour operates currently. His argument is based on the premise that effective union renewal must be driven by the need to respond to, and counter, the spreading influence of global capital. To this end, Borgers (1999) highlights the vast disparities between the organising capacities of transnational capital and that of labour as the key argument for cross-border union solidarity. Questions relating to the difficulties for unions in establishing such bonds across national borders remain largely unresolved.

In this paper we have sought to highlight and discuss the challenges for labour in the emerging global economic context, the need for effective renewal through cross-border union mergers, and the impediments to such mergers. We argue that due to the nature of rapid transformations in business processes, business organisations rarely establish restrictive institutional configurations to undermine their adaptive capacity. This is unlike unions, which, after many years of established spaces, structures and patterns, seem to struggle adapting to a drastically altered global political economy.

The seafaring sector is not only uniquely global but the shipboard workplace is also ordinarily multinational. Whereas this is not necessarily unusual, consideration must be made to the high propensity for shipowners to freely and easily shift the nationality of their primary assets - the ship from one nationality to another in search of the most profitable business conditions, thus completely replacing the regulatory framework for work and employment for seafarers. This way, they have succeeded in circumventing both state regulations as well as union influence regarding seafarer employment terms and working conditions, whenever they do not suit their cost and profit objectives.

Furthermore, as different national labour segments compete for job opportunities and fight over 'stolen jobs', the power of organised seafaring labour, formerly based on firm international solidarity (Kirby 2008), has declined. A representative glimpse of the resulting tensions and suspicions at the workplace level was presented through interview data collected from seafarers of different nationalities on board ship. The data reveal the depth of the segmentation and division among workers in the workplace. This situation is not unique to shipping and workers in other sectors where global competition is flourishing (such as finance and IT) are also keenly aware of their own vulnerability (see Brown et al. 2010).

Drawing on interviews with leading officials and Council members of Nautilus International the paper has examined the potential for, and impediments to, union renewal through a merger of unions across different countries. The analysis reinforces Gallin's (2002) observation that extensive crossborder mergers are indeed considered utopian. It shows that, although the union's conception envisaged international solidarity within and beyond Europe, an extensive global or even Europe-wide union for seafarers is a distant ideal. The biggest obstacle, seemingly, is that unions, generally, are constrained by an established and rigid definition of membership and space. This way, as also observed by Cumbers (2004), unions find themselves constrained to the national space, just as NI's internationalisation agenda seems dictated and constrained by notions of core members' interests and like-mindedness, i.e. institutional structures deeply rooted within the nation-state. The notion of like- 
mindedness, which seems to greatly restrict NI's internationalisation options also mirrors Holtgrewe and Doellgast (2012)'s conclusion that unions find it difficult to break out of established structures and attitudes in order to adapt to changing global circumstances. Nevertheless, the NI presents a unique break away from the grooves of traditional structures and sets an important example to emulate as unions re-engineer their organising structures according to the emerging order.

\section{NOTES}

1. This is the process of taking ships out of national registers and operating them under foreign ones, often for the purposes of avoiding strict operations regulations and reducing corporation taxes.

2. The ILA organises marine workers in the US's East Coast, Canada, the Gulf Coast, the Great Lakes and Puerto Rico. For more information on the ILA and MM\&P refer to their websites at www.bridgedeck.org (MM\&P) and www.ilaunion.org (ILA).

3. SIU represents US merchant mariners sailing aboard US-flagged vessels in deep sea, Great Lakes and inland trades. Refer to www.seafarers.org.

4. NB this has not been found to characterise relations on vessels with many nationalities employed on board (see Sampson 2013 for further insight).

5. In this case pilots refers to sea-pilots who have a role in guiding vessels into port. It does not refer to airline pilots.

6. The National Union of Rail, Maritime and Transport Workers (RMT) is a British trade union, representing members in almost every sector of the transport industry, from mainline and underground rail to shipping and offshore, buses and road-freight. Traditionally most of the British ratings are part of the RMT while the officers formed part of NUMAST (now Nautilus-UK).

\section{REFERENCES}

Alderton, T., Bloor, M., Kahveci, E., Lane, T., Sampson, H., Thomas, M., Winchester, N., Wu, B., and Zhao, M. (2004) The Global Seafarer: Living and Working Conditions in a Globalised Industry. Geneva: ILO.

Baccaro, L., Hamann, K. and Turner, L. (2003) 'The Politics of Labour Movement Revitalisation: The Need for a Revitalised Perspective', European Journal of Industrial Relations 9(1): 119-133.

Bergantino, A.S. and Marlow, P.B. (1997) An Econometric Analysis of the Decision to Flag Out. Cardiff: SIRC. 
BIMCO/ISF (2005) Manpower Update: The World-wide Demand for and Supply of Seafarers. The University of Warwick: Institute for Employment Research

Bloor, M., Sampson, H. (2009) 'Regulatory Enforcement of Labour Standards in an Outsourcing Industry: The Case of the Shipping Industry', Work Employment and Society 23(4): 711-726.

Boeri, T., Brugiavini, A. and Calmfors, L. (2001) The Role of Unions in the Twenty-First Century: A Report for the Fondazione Rodolfo Debenedetti. Oxford: Oxford University Press.

Borgers, F. (1999) 'Global Unions-Beyond the Rhetoric: The CWA North Atlantic Alliance', Labour Studies Journal 24(1): 107-122.

Brown, P., Lauder, H., Ashton, D. (2010) The Global Auction: The Broken Promises of Education, Jobs and Rewards. New York: Oxford University Press.

Chaison, G.R. (1980) 'Note on Union Merger Trends, 1900-1978', Industry and Labour Relations Review 34: 114-120.

Cooper, A.D., Walsh, C.J., Stranberry, B.A. and Boerne, G.L. (1999) Voyages of Abuse: Seafarers, Human Rights and International Shipping. London: Pluto Press.

Cooper, A. (2000) 'Implications of Maritime Globalisation for the Crews of Merchant Ships', Journal of Maritime Research 2(1): 1-8.

Crouch, C. and Streeck, W. (eds) (1997) Political Economy of Modern Capitalism: Mapping Convergence and Diversity. Sage: London.

Cumbers, A. (2004) 'Embedded Internationalism: Building Transnational Solidarity in the British and Norwegian Trade Union Movements', Antipode 36(5): 829 - 850.

Dawson, P. (2003) Understanding Organisational Change: The Contemporary Experience of People at Work. Sage: London.

Ebbinghaus, B. and Visser, J. (1999) 'When Institutions Matter: Union Growth and Decline in Western Europe, 1950-1995', European Sociological Review 15(2): 135-158.

Fiorito, J. and Gallagher, V.C. (2006) 'Renewal in the United Faculty of Florida: Class War in Paradise?' Labor Studies Journal 31(3): 39-64.

Gallin, D. (2002) 'Labour as a Global Social Force: Past Divisions and New Tasks', in J. Harrod and R. O'Brien, R. (eds), Global Unions? Theories and Strategies of Organised Labour in the Global Political Economy (pp. 235-250). London: Routledge.

Gekara, V.O. (2009) 'Understanding Attrition in UK Maritime Education and Training', Globalisation Societies and Education 7(2): 217-232. 
Gekara V.O. (2010) 'Union Renewal through Cross-border Merger: Rationale, Processes and Challenges - the Nautilus International Merger', The European Journal of Industrial Relations 16(4): $385-394$.

Gennard, J. and Judge, G. (2005) Employee Relations. $4^{\text {th }}$ Edition. London: Chartered Institute of Personnel and Development.

Glen, D. (2008) 'What Do We Know About the Labour Market for Seafarers? A View From the UK', Marine Policy 32(6): 845-855.

Hannerz, U. (1996) Transnational Connections: Culture, People, Places. London: Routledge.

Harvey, D. (2006) The Limits of Capital. London: Verso

Herod, A. (1997) 'Labor's Spatial Praxis and the Geography of Contract Bargaining in the US East Coast Longshore Industry, 1953-1989’, Political Geography 16(2): 145-169.

Holtgrewe, U. and Doellgast, V. (2012) 'A Service Union's Innovation Dilemma: Limitations on Creative Action in German Industrial Relations', Work Employment Society 26: 314-330.

Hyman, R. and Gumbrell-McCormick, R. (2010) 'Trade Unions and the Crisis: A Lost Opportunity?' Socio-economic Review 8(2): 364-372.

Janus, C.J. (1978) 'Union Mergers in the 1970's: A Look at the Reasons and Results', Monthly Labour Review 101: 13-23.

Johns, R. (1998) 'Bridging the Gap Between Class and Space: US Worker Solidarity with Guatemala', Economic Geography 74(3): 252-272.

Kahveci, E. and Nichols, T. (2006) The Other Car Workers: Work, Organisation and Technology in the Maritime Car Carriers Industry. Basingstoke: Macmillan.

Kennedy, P. and Rondometof, V. (2007) Communities Across Borders: New Immigrants and Transnational Cultures. London: Routledge.

Kirby, D. (2008) Voices from the Ships: Australia's Seafarers and their Union. Sydney: University of New South Wales (UNSW) Press.

Lane, T. (2000) 'The Global Seafarers Labour Market: Problems and Solutions', available online at: www.itfglobal.org/seafarers/icons-site/images/93SIRC.pdf. [Accessed 14 February 2013].

Lévesque, C. and Murray, G. (2010) 'Local Union Strategies in Cross-border Alliances: From Defensive Isolation to Proactive Solidarity', Labor Studies Journal 35(2): 222-245.

Lillie, N. (2004) 'Global Collective Bargaining on Flag of Convenience Shipping', British Journal of Industrial Relations 42(1): 47-67. 
Lillie, N. (2006) A Global Union for Global Workers: Collective Bargaining and Regulatory Politics in Maritime Shipping. London: Routledge.

Morrison, C., Croucher, R. and Cretu, O. (2012) 'Legacies, Conflict and "Path Dependence" in the Former Soviet Union’, British Journal of Industrial Relations 50(2): 329-351.

Munck, R. (2002) Globalisation and Labour: The New Great Transformation. London: Zed Books Ltd.

Peck, J. (2007) 'European Historical Economics and Globalisation', The Journal of Philosophical Economics 1(1): 22-52.

Peck, J., Theodore, N. and Ward, K. (2005) 'Constructing Markets for Temporary Labour: Employment Liberalization and the Internationalization of the Staffing Industry', Global Networks 5(1): 3-26.

Peters, G.B., Pierre, J. and King, D.S. (2005) 'The Politics of Path Dependency: Political Conflict in Historical Institutionalism', The Journal of Politics 67(4): 1275-1300.

Pierson, P. (2000) 'Increasing Returns, Path Dependence and the Study of Politics', American Political Science Review 94(1): 251-66.

Pries, L. and Seeliger, M (2013) 'Work and Employment Relations in a Globalized World: The Emerging Texture of Transnational Labour Regulation', Global Labour Journal 4(1): 26-47.

Rodney, C. (1981) Sovereignty for Sale: the Origins and Evolution of the Panamanian and Liberian Flags of Convenience. Annapolis: Naval Institute Press.

Sampson, H. (2003) 'Transnational Drifters or Hyperspace Dwellers: An Exploration of the Lives of Filipino Seafarers Aboard and Ashore', Ethnic and Racial Studies 26(2): 253-77.

Sampson, H. (2012) 'Globalisation, Labour Market Transformation and Migrant Marginalisation: The Example of the Transmigrant Seafarers in Germany', Journal of International Migration and Integration. Available at: http://link.springer.com/article/10.1007/s12134-012-0266-0.

Sampson, H. (2013) International Seafarers and Transnationalism in the Twenty-first Century. Manchester: Manchester University Press

Sander, H. (1996) 'Multilateralism, Regionalism, and Globalization: The Challenges to the World Trading System', in H. Sander and A. Inotai (eds), World Trade After the Uruguay Round (pp. 17-36). London: Routledge.

Sletmo, G.K. and Holste, S. (1993) 'Shipping and the Competitive Advantage of Nations: The Role of International Ship Registers', Maritime Policy and Management 20(3): 243-255. 
Steinmo, S., Thelen, K., and Longstreth, E. (eds) (1992) Structuring Politics: Historical Institutionalism in Comparative Perspective. Cambridge: Cambridge University Press.

Tope, D. (2009) 'The Politics of Union Decline: The Contingent Determinants of Union Recognition Elections and Victories', American Sociological Review 74(5): 842-864.

Umney, C. (2012) 'Managerial and Mobilizing Internationalism in the British Docks and Seafaring Sector', European Journal of Industrial Relations 18(1): 71-87.

Wu, B. (2004) 'Participation in the Global Labour Market: Experiences of Chinese Seafarers', Maritime Policy and Management 31(1): 69-82.

Wu, B. and Sampson, H. (2005) 'Reconsidering the Cargo Sector's Seafarer Labour Market: A Twentyfirst Century Profile of Global Seafarers', Ocean Yearbook 19: 357-380.

Yannopoulos, G.N. (1988) 'The Economics of "Flagging Out”, Journal of Transport Economics and Policy 22(2): 197-207.

\section{BIOGRAPHICAL NOTE}

VICTOR OYARO GEKARA is a Senior Lecturer in the School of Business IT and Logistics at RMIT University in Melbourne, Australia. His broad research interests are in International Political Economy with specific reference to global labour, work and employment. An important part of his recent work has involved research on issues related to the organisation and employment of labour in the seafaring sector. He has previously worked as a researcher at, and continues to associate closely with, the Seafarers International Research Centre, Cardiff. [email: victor.gekara@rmit.edu.au]

IRIS L. ACEJO is currently completing her $\mathrm{PhD}$ study on transnational assimilation of Filipino seafarers, through the SIRC-Nippon Foundation Fellowship programme. She also works as a Research Assistant at SIRC. [email: AcejoI@cf.ac.uk]

HELEN SAMPSON is a professor at Cardiff University School of Social Sciences and Director of the Seafarers International Research Centre. Her broad research interests include the development and regulation of labour under globalisation, with specific reference to the maritime sector. [email: SampsonH@cf.ac.uk] 